Western University

Scholarship@Western

Spring 4-30-2020

Gwaabaw: Applying Anishinaabe Harvesting Protocols to Energy Governance

Sakihitowin Awasis

Western University, cdakin2@uwo.ca

Follow this and additional works at: https://ir.lib.uwo.ca/geographypub

Part of the Geography Commons, and the Legal Studies Commons

Citation of this paper:

Awāsis, S. 2020. Gwaabaw: Applying Anishinaabe Harvesting Protocols to Energy Governance. The Canadian Geographer/Le Géographe canadien. doi.org/10.1111/cag.12615. 


\section{Gwaabaw: Applying Anishinaabe Harvesting Protocols to Energy Governance}

Sākihitowin Awāsis

Department of Geography, Western University

Correspondence to / Adresse de correspondance: Sākihitowin Awāsis, Department of Geography, Western Social Science Centre, Western University, 1151 Richmond St., London, ON N6G 2V4 Email/Courriel: cdakin2@uwo.ca

Acknowledgements

I am deeply grateful for Niiobinesiik Summer Bressette's generous sharing, grounded vision, and invaluable guidance, as well as Dr. Carol Hunsberger's encouragement and support while developing ideas that are central to this paper. I also extend immense gratitude to my shkaabewis (helper) niizhoo-migizikwe Shawna Redskye. Lastly, this research is supported in part by funding from the Social Sciences and Humanities Research Council.

This is the submitted version of the following article: Awāsis, S. 2020. Gwaabaw: Applying Anishinaabe Harvesting Protocols to Energy Governance. The Canadian Geographer/Le Géographe canadien. The article has been published in final form at doi.org/10.1111/cag.12615.

Abstract

Oil and gas extraction has transformed Anishinaabe society in ways that undermine the consensual, holistic, and egalitarian basis of natural law. To many Indigenous people, framing fossil fuels and other energy sources as "natural resources" does not accurately define energy projects or capture related risks. Some Anishinaabe pipeline opponents have suggested that traditional harvesting protocols-culturally embedded moral precepts that govern the gathering of food and medicinal plants-also be applied to activities that produce energy. This paper explores how this could be done, focusing on tar sands extraction and the Line 3 expansion plan. I begin by discussing Anishinaabe harvesting protocols, identifying four overlapping key concepts: rights, responsibility, relationality, and reciprocity. These principles are then mapped onto Anishinaabe understandings of oil, hydro, wind, and solar energy. The resulting analysis challenges extractivist narratives of energy production, opening possibilities to rethink the relationship between people and energy as well as the values that inform energy decisions.

Keywords: Indigenous geographies, self-determination, energy governance, Anishinaabe studies

\section{Key Messages:}

- Colonial extractivism has significantly impacted Anishinaabe governance and ways of living.

- Harvesting protocols related to principles of rights, responsibility, relationality, and reciprocity can guide the decolonization of energy decision-making processes.

- Further research is needed on how humans and non-humans can collaborate in decisionmaking. 


\section{Bagijigan (an offering)}

Anishinaabe Aki, the homelands of the Anishinaabeg confederacy, stretches from the eastern woodlands of Gichigamiin (the Great Lakes) to the prairie grasslands in the west, including territories shared with neighboring human and nonhuman nations. Freshwater seas, lakes, and rivers ebb and flow through forests that range from boreal to deciduous and comprise the foundation of who I am as a Michif Anishinaabe niizh manidoo (two-spirit) of the Waabizheshi Dodem (Pine Marten Clan). I am from Wemitigoj Sibi (French River) and live along Deshkan Ziibiing (Antler River) where, as part of a sun dance family, I regularly attend sweat lodge ceremonies. When coming out of lodge, often a wooden bowl of berries is passed around the circle; luscious and thirst-quenching strawberries, raspberries, saskatoon berries, blueberries, or mulberries to share. Before any are eaten by an Anishinaabe, some are lovingly given back to the earth and manidoog (spirits). Bagijige, making an offering, is an act of gift giving that adheres to Chi Inaakonigewin (natural law). Chi Inaakonigewin is Anishinaabe law that can be observed in the environment and helps build good relations among humans and with the natural world (Borrows 2016). In its many different forms, bagijige is an acknowledgment of value, vow of respect, and affirmation of another being (Doerfler et al. 2013).

I begin with this story to illustrate several ideas that are integral to understanding how Anishinaabe legal systems can more fully facilitate just energy governance. First, offerings can be declined. If I was fasting from berries for instance, I would gently touch the brim of the bowl to acknowledge the gifts but choose not to indulge. Natural law relies on consensuality between humans and nonhumans. Second, there is a bottom of the bowl. I cannot endlessly take, gifts are not limitless (Kimmerer 2015). The holistic basis of natural law is concerned with understanding and working within the land's inherent limits (Borrows 2018). Third, everyone eats from the same bowl and with the same spoon (Kimmerer 2015). When the bowl reaches me in circle, I look to my relations and may only take a single berry or small handful to ensure everyone in the circle can have an equal share. The egalitarianism of Chi Inaakonigewin extends to Anishinaabe dodemiwan (clan governance). Dodemiwan is consensus-based, a bottom-up leadership model in which women, men, and two-spirit gimaag (chiefs) serve the people and land as spokespeople (Giniwgiizhig 2013). Dodemiwan is comprised of intricate relationships to local ecosystems and ceremonial life; all political and spiritual power is understood to come from the land.

Anishinaabe teachings consider it humans' role not to control the world around them, but to learn from the land how to be human. The land is not a commodity, property, or real estate; the land is all that sustains us: our kin, identity, and ways of knowing (Kimmerer 2015).

To many Indigenous people, framing fossil fuels and other energy sources as "natural resources" does not accurately define energy projects or capture related risks. The term suggests that natural resources exist for humans' use, control, and exploitation (Preston 2017). Natural resource extraction has drastically reshaped Anishinaabe Aki, violating the consensual, holistic, and egalitarian basis of natural law. Extractivism, a model of development based on resource extraction, has also largely disrupted the eco-social system of Anishinaabe clan governance. Effects of the extractivist mode of development include environmental degradation, dispossession of Indigenous peoples, and the concentration of wealth. Emerging from Indigenous and environmental critiques of the Latin American new left in the early 1990s, extractivism 
discourse links European colonialism to contemporary resource policies (Riofrancos 2017). With an expansive spatiotemporal understanding, extraction can be conceptualized across a wide range of practices to make connections between the operations of capitalism and the land. In this sense, extraction encompasses any process through which value is generated for capitalist systems (Szeman 2017). This includes the North American fur trade, harvesting food and lumber, the residential school system, and data mining. Capitalist economies require a continuous input of a variety of resources.

The concrete social and environmental impacts of extractivism make it incompatible with natural law in Anishinaabe Aki. In 2010, Enbridge Line 6b ruptured, spilling approximately 1 million gallons of bitumen into the Kalamazoo River (Grant 2014; Pickren 2019). In April 2018, a Husky refinery in Superior, Wisconsin caught fire and exploded, resulting in 15 injuries and emergency evacuations (Blair-Frasier 2018). Aamjiwnaang, an Anishinaabeg community near Sarnia, Ontario, is surrounded by chemical valley, the largest complex of petrochemical conglomerates in Canada (Luginaah et al. 2010). Community members' constant exposure to harmful emissions and contaminants from industrial operations results in some of the highest morbidity and mortality rates for cancers and, respiratory and neurological diseases in Ontario (Atari et al. 2008; Cryderman et al. 2016).

Land-based knowledge systems have enabled Indigenous peoples to survive both genocide and ecosystem collapse. Globally, the accelerating rates of extinction for flora and fauna as well as Indigenous languages are alarming; every day entire species go extinct and Indigenous knowledge is lost (Barnosky et al. 2011; Reyes-García et al. 2013). Indigenous peoples of Mikinaak Minis (Turtle Island or North America) disproportionately face the landbased health impacts of environmental degradation and climate change (Richmond and Ross 2009; Durkalec et al. 2015). Extractivism accelerates environmental impacts in Gichigamiin (the Great Lakes) region of Anishinaabe Aki. Climate models project extreme changes in climate over a 30-year period that will likely have many critical impacts on human and ecosystem health (Byun and Hamlet 2018). Byun and Hamlet (2018) predict amplified risks of extreme heat events, precipitation, floods, and droughts, as well as reduced snow and ice cover, and increased air and water temperatures, resulting in wetter winters and drier summers. The water level of Gichigamiin is also expected to decrease while 'dead zones' intensify and major changes to fire regimes could convert woodland forests to grasslands in a few decades (Byun and Hamlet 2018). This poses unique challenges for the preservation of Anishinaabe knowledge systems which are at risk of being irreversibly impacted by resource extraction and climate change (Big-Canoe and Richmond 2014). There is an urgent need to articulate alternatives to extractivism based in Indigenous ways of knowing. Inspired by interviews with Anishinaabe pipeline opponents, this research asks: (1) How can Anishinaabe harvesting protocols shape understandings of oil, hydro, wind, and solar projects? And (2) how can these insights be applied to energy projects? Answering these questions can contribute to more just and sustainable energy decisions through the resurgence of Indigenous legal systems in energy governance.

To answer these questions, I take a biskaabiiyang or "decolonizing" approach drawing on my lived experience as a Michif Anishinaabe niizh manidoo (two-spirit). In Anishinaabemowin (the Anishinaabe language), the word biskaabiiyang describes the process of decolonization as "returning to ourselves" (Geniusz 2009). This approach seeks to decolonize Anishinaabe people and ways of knowing by describing concepts within Anishinaabe culture and language. Anishinaabemowin provides meanings that cannot be expressed in English because cultural 
knowledge embedded in our languages is lost in translation (Corbiere 2013). Anishinaabe scholars refer to these embedded cultural norms as a "language of animacy" (Kimmerer 2015; Borrows 2018). Anishinaabemowin is verb-based, the world is understood to be alive and in constant motion. For example, in English one is either a human or a thing, and humans are gendered, a they, she, or he, while a nonhuman is reduced to it. When we view a nonhuman as an object instead of a subject, we absolve ourselves of moral responsibility and open opportunities for exploitation (Kimmerer 2015). The English language can implicitly permit a disrespect for nature by denying some beings the right to be regarded as persons. In Anishinaabemowin, all living beings are considered someone, not something, and there are no gendered pronouns. The failure of the English language to encapsulate Anishinaabe concepts indicates that language assimilation poses an additional threat to the continuity of Indigenous knowledge systems (Pine 2016).

Anishinaabe language and law carry guidance from the earth's functions around us (Borrows 2018). The implications for energy governance are immense. This article will begin by articulating gkendaasowin (knowledge) about Chi Inaakonigewin (natural law) as a source of bimaadiziwin (a way of living) and dibenindizowin (self-determination). Next, a critique of extractivism emphasizes the role of capital investments, perceived scarcity, and technological advancements, and focuses on a political ecological analysis of the Athabasca tar sands boom. Principles of natural law that govern harvesting practices with culturally embedded protocols are then discussed. I begin by identifying four overlapping key concepts: rights, responsibility, relationality, and reciprocity. These principles are then mapped onto Anishinaabe understandings of the Line 3 expansion plan, as well as oil, hydro, wind, and solar energy. The resulting analysis challenges extractivist narratives of energy production, opening possibilities to rethink the relationship between people and energy as well as the values that inform energy decisions.

\section{Gkendaasowin (knowledge)}

Anishinaabe gkendaasowin is embodied and land-based Indigenous knowledge that is specific to Anishinaabeg peoples. Gkendaasowin is embodied knowledge because it is lived, experienced, and attained by years of "doing" (Pine 2016). Anishinaabe bimaadiziwin (ways of living) involve the embodiment of gkendaasowin in relationship with the land. Gkendaasowin is gained through direct involvement with knowledge keepers who have accrued a lifetime of observation, activity, and direct interaction with the land. Located in the lived experience of families, communities, and past and future generations, gkendaasowin cannot be separated from the land; the knowledge needed to live sustainably exists in the landscape (Pine 2016).

As an Anishinaabe person, I am simultaneously enmeshed in an environment that is both material and spiritual (Pine 2016). The land can be understood as a set of "relationships of things to each other" (Deloria 2001, 23), or as our "self-in-relation" (Kovach 2009, 27). Within an Anishinaabe ontology, all plants, animals, trees, rocks, rivers, and lakes are sentient beings who have their own spirit, personality, language, knowledge, and law. The land encompasses diverse ways of knowing, experiencing, and relating with the world (Wilson 2008). Aki (land) is Anishinaabe peoples' first family and our main teacher (Kimmerer 2003; Dumont 2015). This deep interrelatedness with the land engenders an ethics that guides conduct and interactions with both human and nonhuman kin (Borrows 2010; Daigle 2016). 
Chi Inaakonigewin (natural law) draws analogies from the land and behaviour of nonhumans, and is recorded in a variety of media, including stories, songs, scrolls, wampum belts, blankets, sashes, rocks, and paper (Borrows 2019). Anishinaabemowin and Chi Inaakonigewin conjoin, organize, and detail dynamic ways of being in ever-changing eco-social processes. Chi Inaakonigewin is generated by lively community deliberation and promotes mino bimaadiziwin (a good way of life) (Borrows 2019). More generally, natural law theory involves the view that certain rights and notions of justice are inherent to human nature prior to the existence of any system of human-made positive law derived from a central authority (Gormley 1984; Napoleon 2013). Practical reasonability and sociability are considered basic human goods (Gormley 1984; Brewer 2006; Napoleon 2013; Ferreira da Cunha 2013). Natural law is a dialectical methodology derived through practical reasoning, which helps in establishing autonomy and choosing ways to do good. Natural law is in place to support the flourishment of human societies, formulated to foster social order that enables humans to live more harmoniously among each other. The cooperative formation of communities is essential for survival and the attainment of further good. Natural law can be considered to reside in nature; nature has the power to legislate, and is not only pedagogical, but moral (Ferreira da Cunha 2013).

However, dominant conceptualizations of natural law have focused on human nature and human communities. A persistent problem is the subjugated agency of nonhumans; even when applied to nonhumans, the concepts of agency and personhood are modified and limited (Middleton 2015; Burow et al. 2018). Indigenous critiques of sovereignty are often based on the concept's inability to adequately account for intersocietal relations between humans and nonhumans (Carroll 2014; Simpson 2017). Mino bimaadiziwin (a good way of life) can be understood as the mutual flourishing of interconnected human and nonhuman communities (Simpson 2011; Doerfler et al. 2013). The animals adopted us, and we could not live without our kinship relations with them (Dumont 2015). Dodemiwan (clan governance) relies on nonhumans' support for Anishinaabeg and provides a cultural, spiritual, political, and social ordering for Anishinaabe society (Jewell 2018). Dodemiwan is the application of Chi Inaakonigewin in Anishinaabe society. Dodem, the Anishinaabe word for clan, comes from ode, meaning heart. Sinclair (2013) stresses how the heart is an organ embedded in a reciprocal system; ode sends blood throughout the body that is later returned to the heart via multiple different entry and departure points. Similarly, dodeman (clans) are living beings that Anishinaabe are in reciprocal relationship with in a multiplicity of ways. Anishinaabewin (lived expressions of being Anishinaabe) celebrate autonomy and variance, and exude queer normativity when difference is not treated as difference, but as normal (Simpson 2017).

Anishinaabe dibenindizowin (self-determination) is the ability of Anishinaabe people to independently decide the extent and nature of our governance structures (Willow 2013). Dibenindizowin can be understood as a process that relies on the continued option to access an undegraded land-base that could support dodemiwan. Restoring our relationships with plant and animal nations is significant for the restoration of Anishinaabe self-determination (Simpson 2013). Externally imposed resource extraction regimes, explored further in the sections that follows, threaten the intergenerational transmission of Anishinaabe gkendaasowin, bimaadiziwin, and dibenindizowin because they threaten the lands that make embodiment possible. It is often land-based ways of knowing and living that drive Indigenous peoples' struggle for self-determination and resistance to colonialism (Coulthard 2010). 


\section{Colonial resource making and extractivism}

Extractivism is not simply use of the natural environment, which is something Anishinaabe people have been doing in Mikinaak Minis (Turtle Island) since time immemorial. Extractivism is both principle and practice, it is a way of living that values lands not in and of themselves, but for the profits they can produce (Willow 2016). Scholarship on extractivism describes extractive activities, the policies that support them, socio-environmental effects, and the forms of resistance they incite, as well as discourses articulated by situated actors that critique specific regimes of resource governance (Veltmeyer 2013; Svampa 2015; Gustafson and Guzmán Solano 2016; Riofrancos 2017). Political ecology scholars examine how power relations and technologies of extraction produce new frontiers of accumulation (Valdivia 2015). In this approach, social structures are used to contextualize natural resources in power relations that govern an uneven distribution of wealth. The making of natural resources is a political, economic, and cultural process that is configured by global capitalism (Bridge 2011).

In Mikinaak Minis (Turtle Island) colonial relations are characterized by interrelated economic, gender, racial, and state powers that comprise hierarchical social structures and continue to facilitate the dispossession of Indigenous peoples of our lands and selfdetermination. Colonial decision-making invalidates Indigenous self-determination by violating Indigenous political and economic systems, transforming non-capitalist relations into economic relations, and demanding communities remain open to capitalist development (Coulthard 2014). Extractivism demands the dispossession of Indigenous peoples from the land and land-based governance to access "resources" that are removed from their place of origin, where they provide emplaced benefits (Willow 2016).

Benefits flow out of Indigenous communities, while local people disproportionately bear social and environmental burdens (Willow 2016). Through extractivism, natural resources became a vehicle for not only the concentration of wealth, but also decision-making power and territorial control (Veltmeyer and Bowles 2014; Valdivia 2015). The speed and scale of extraction is intensified by global trade networks and large capital investments (Jalbert 2017). The export-oriented, resource-intensive model of accumulation is also intensified by technological advancements and a scarcity-based approach to energy that enables industry to access resources that were previously considered inaccessible or uneconomical (Willow 2016). Perceived scarcity creates demand and unmet desires (Kimmerer 2015). Extractivist schemes imposed on Indigenous communities, including refinement, transport, and consumption, are experienced culturally and can be interpreted politically for Anishinaabe people.

On neighbouring Denesuline and Nîhithaw territory, the Athabasca tar sands exemplify colonial extractivism on an unprecedented scale (Preston 2017). The extraction of resources on a scale this enormous has physically rearranged and permanently scarred the landscape. The tar sands cover $140,000 \mathrm{~km}^{2}$ of land, comparable in size to the state of Florida, resulting in the exposure of species to toxic contaminants and destruction of rich boreal forest, wetland, and river ecosystems that provide habitat for wildlife (Wells et al. 2008; Jordaan 2012; Arens et al. 2017). Health impacts include disproportionately high rates of rare cancers and respiratory illnesses in Indigenous communities near the mega project (Westman and Joly 2019).

The 1990s ushered in one of the largest resource booms in North American history through massive increases in oil and gas industry investment in the tar sands. Oil corporations spent $\$ 50$ billion on new projects between 1996 and 2006, and roughly $\$ 201$ billion in existing projects between 1999 and 2013 (Urquhard 2018). Dramatic investments also meant dramatic 
increases in production. While tar sands production in 1996 averaged nearly 432,000 barrels per day (bpd), by 2015 levels exceeded 2.38 million bpd. The tar sands boom has partially been driven by new recovery technologies such as in-situ bitumen extraction (pumping steam underground to mobilize oil) which has enabled extraction from previously unproductive wells (Pickren 2019).

Extraction depends on infrastructure to transport resources, comprising a complex political, ecological, and economic web of relationships between the points of extraction and consumption (Valdivia 2008; Riofrancos 2017). For example, pipelines, pump stations, storage facilities, railroads, and highways all connect the tar sands to refineries and coasts for export. Diluted bitumen is increasingly being carried through the Great Lakes region via the Enbridge Pipeline System (Enbridge 2019). Heavier crudes such as bitumen require more intensive and costly refining processes to produce the derivatives desirable to capitalist society (Valdivia 2008). Facility upgrades have been conducted along Enbridge pipeline routes to enable refineries to process the bitumen sourced from the Athabasca (Pickren 2019). The pipeline network accommodates tar sands expansion, as well as the further entrenchment of capitalist relations and carbon lock-in. The landscape has been spatially reconfigured to meet the energy demands of capitalism and reinforce fossil fuel dependencies. As a result, tar sands extraction and pipeline systems have become a focal point of protest (Wong 2013).

There is mounting Anishinaabeg resistance to pipeline projects throughout Anishinaabe Aki, including opposition to the Line 9 reversal, Line 3 replacement program, Line 4 expansion project, and the continued operation of Line 5 (LaDuke 2015; Cragoe 2017; Hearne 2017; Hunsberger and Awasis 2019). Across Mikinaak Minis Anishinaabeg peoples are engaged in political, discursive, and epistemic battles against extractivism. Extractivism is based on an asymmetry of political power. Typically, it is distant decision makers, including government officials, corporate executives, and investors that benefit while local Indigenous lands and the cultures they sustain are violently disrupted (Willow 2016). Destructive colonial practices are framed as an unintended consequence of economic development (Nelson 2013). Extraction is a kind of epistemic violence that removes all of the relationships that give what is being extracted meaning in Anishinaabe ways of knowing; that is, it changes how we know it (Simpson and Klein 2013). In this sense, colonialism is also extracting Indigenous knowledge, what it means to be Indigenous, and Indigenous peoples themselves from the landscape.

While scholars depict a fundamental conflict between extractivism and Indigenous ways of living, others document more heterogenous Indigenous responses, acknowledging that Indigenous peoples may seek to participate in and benefit from extractive industries (Anthias 2018). Anishinaabe people have protested and supported all the forms of energy discussed in this article. Rather than trying to characterize variant community positions on specific projects, my aim is to emphasize aspects of Anishinaabe gkendaasowin and Chi Inaakonigewin that may be helpful for others carrying out work for Indigenous self-determination and decolonial energy governance.

More recently emerging scholarship on extractivism approaches tracing geopolitics by following the connections of human and nonhuman assemblages and alliances (Valdivia 2015; Navarrete-Segueda 2017). Notably, in 2017 Aotearoa (New Zealand) and Hindustan (India) recognized the Whanganui River and Ganges River respectively as possessing legal personhood (Borrows 2018). Ecuador also adopted Rights of Nature in the 2008 constitution, while Indigenous leaders raised two main concerns (Valladares and Boelens 2017). First, Indigenous understandings of nature do not separate the concept from their social organization; it does not 
make sense for humans to give rights to nature, when it is nature that gives people rights. Second, the Rights of Nature grant the state a novel way of regulating and controlling a domain of Indigenous communities that had previously existed exclusively outside the colonial legal system. Critiques of extractivism radically decentre humans; elements of the natural world are not only the subject of rights, but active members of the polity (Riofrancos 2017). Indigenous people not only seek to reframe place-based resistance among multiscalar conflicts with hydrocarbon reliant states, they also seek to reconfigure the relationship between land and extraction in the context of larger struggles for self-determination (Anthias 2018).

\section{Anishinaabe Harvesting Protocols}

Anishinaabeg peoples have survived ecological and cultural genocide by speaking with and hearing the land to develop meaningful personal relationships (Nelson 2013). Harvesting protocols - culturally embedded precepts that govern hunting and the gathering of food and medicinal plants - are one important way in which these relationships are expressed. While I was conducting interviews on Anishinaabe pipeline resistance for another project, Niiobinesiik (Summer Bressette) initially raised the idea that Anishinaabe harvesting protocols might provide a useful way to rethink humans' relationship to energy sources. Following up on their suggestion, in this section I provide a summary of traditional harvesting protocols, experiences, and knowledge, followed by an overview of four main principles: rights, responsibility, relationality, and reciprocity. I will then apply these principles to understandings of energy sources.

In Anishinaabemowin the word for harvest refers specifically to what you are harvesting. It describes a unique relationship to that individual plant or animal: for example, manoominike (s/he harvests wild rice), mawinzo (s/he picks berries), and naadoobii (s/he gathers sap) (Nichols 1995). I chose the animate verb gwaabaw to describe the process of harvesting energy, which literally translates to "to pick something out (of water/fire) with an instrument" (Valentine 2001, 448). Within Anishinaabe society there is a multiplicity of embedded moral precepts that guide harvesting (Lariviere and Crawford 2013). Harvesting protocols have developed over time as an extension of natural law to ensure that life is sustained (McGregor 2013). It is important to note that Indigenous community-based value systems are local cultural expressions that are spatiotemporally distinct. Efforts to identify principles of harvesting in relation to energy development must also recognize that these constructs do not exist in isolation and are deeply embedded in complex cultural and social customs (Lariviere and Crawford, 2013). Recall queer normativity, Indigenous cultures consist of great diversity and no single set of principles can represent the practices of all Anishinaabe people. Different individuals, families, and communities all use different methods to embody harvesting principles.

When I go to harvest medicines, I take the time to get to know the community. I find a leader, for instance, the largest of sage plants growing in a patch. I approach them with semaa (tobacco) in hand, careful not to disturb their neighbours. I introduce myself and where I come from. I address the plant by their Anishinaabe name if I know it. Sage is Mshkodewashk. I say miigwech (thank you) to them for fulfilling their responsibilities, among them creating the very oxygen we breathe. Miigwech literally means "that is enough" (Vukelich 2018). Even if Mshkodewashk does not agree to share their medicine with me, just being who they are is sufficient. I acknowledge my relationship to Mshkodewashk and describe my intentions, why I 
am harvesting them, how much I need, and for what purposes. Plants are not taken, but requested (Kimmerer 2015). I listen intently to whether they consent or not.

We can learn a lot about each other through observation; for example, we can assess whether beings have the capacity to provide for the request and whether it is the appropriate time for harvesting. If permission is given and Mshkodewashk offers their gifts, I have a responsibility to make good use of them. I try to do the least damage possible while harvesting for example, not picking the leaders, and leaving the roots intact. Lastly, I would leave a gift in return. Semaa is usually offered before harvesting plant medicines. Kimmerer (2015) describes this as the Honourable Harvest: take only what you need, use everything you take, do no damage, give thanks, do not take the first or last plant you see, never take more than half or more than you need, take only which is given, reciprocate, and share. The harvesting methods of our Anishinaabe ancestors brought long-term benefits to all species of people and the lands themselves. The ecological knowledge of Anishinaabe harvesters is rich in prescriptions for sustainability.

Decolonial politics are embedded in our daily lives. Traditional harvesting embodies larger systems of Anishinaabe gkendaasowin that are complex and multifaceted. Everyday activities comprise decolonial processes that centre two-spirit roles, responsibilities, and resistance to cis-heteronormativity (Hunt and Holmes 2015). Indigenous bodies are political orders and living representations of land-based governance (Simpson 2017). Based on Anishinaabe teachings, literature, and my own knowledge and experiences as a Michif Anishinaabe niizh manidoo, I propose that four interlinked principles are central to Anishinaabe harvesting protocols: rights, responsibility, relationality, and reciprocity. I will now explore each concept in more detail.

Indigenous peoples have the inherent right to land-based practices and ways of living. For Anishinaabeg, harvesting is a method for enacting governance and dibenindizowin (Yerxa 2014). There is also an implicit understanding that all elements of the natural world have inherent rights and self-determination equal to that of humans (Borrows 1997; Kimmerer 2003; Giniwgiizhig 2013; Lariviere and Crawford 2013). The very act of owning something diminishes its innate sovereignty because part of their nature is lost when dominated and extracted from their origins (Kimmerer 2003). Over-harvesting or taking beyond your immediate needs is highly criticized in Anishinaabeg culture because it infringes on the rights of nonhumans (Borrows 1997; Giniwgiizhig 2013; Lariviere and Crawford 2013). According to Anishinaabeg protocols, humans have the responsibility to respect the rights of nonhuman beings (Kimmerer 2015).

As Anishinaabe legal scholar Borrows (2010) points out, for Anishinabeg the rights and responsibilities of humans and nonhumans are tightly intertwined. When the life and rights of other beings would be significantly disrupted, not harvesting at all is considered appropriate (Borrows 1997). Traditional Anishinaabe harvesters abstain from harvesting more than what is required to meet the needs of their family or community to sustain future harvests and help support regeneration (Lariviere and Crawford 2013). This is especially important in contemporary situations, considering that technologies such as freezers and dehydrators give harvesters the ability to accumulate far beyond their basic needs. Waste avoidance also helps reduce the amount that needs to be harvested to meet the needs of the community.

Many Indigenous peoples feel a responsibility to the seven generations before and after themselves. The Seven Generations Principle comprises the basis of understanding that a person's responsibilities extend beyond the individual (Horn-Miller 2013). In Anishinaabe contexts, harvesting provides opportunities for Anishinaabe people to affirm their land-based 
identity and fulfill their responsibility to sustain gkendaasowin and bimaadiziwin (Norrgard 2009). Anishinaabe harvesting protocols also recognize that nonhumans have their own responsibilities, and they cannot fulfill their responsibilities unless we meet ours (Kimmerer 2003). For example, Mshkodewashk has responsibilities to draw up water to its leaves for rabbits, to shelter young quail, and to the people who use sage to cleanse, meditate, or pray. Plants grow when and where they can fulfill their responsibilities and remember their responsibilities to other beings, even when humans have forgotten (Kimmerer 2003).

When a plant decides to give medicine or sustenance, it is a gift. All living beings have their own unique gifts, and gifts come with responsibilities (Kimmerer 2003). The nature of a plant medicine is changed by how it comes to you, as a gift or commodity: a commodity does not involve an inherent obligation while a gift establishes an ongoing relationship between two people (Kimmerer 2015). In a gift economy, gifts that are freely given away are not made into another's capital. Plants and animals do not "belong" to humans, instead they are understood to have given themselves to the people to survive and flourish (Lariviere and Crawford 2013). This is reflected in harvesters' responsibility to give a large portion, if not their entire harvest, to members of their family, extended family, community, and/or anyone in need of such provisions. Disruptions in the interconnected web of responsibilities jeopardizes land-based relationships that are deeply valued by Anishinaabe people (Pine 2016). Interdependence can be liberating and/or oppressive, depending on how we act towards the land and each other (Borrows 2018).

Relationality informs how we treat the land and each other during the harvesting process (Pine 2016). In Anishinaabe culture, ecological connectedness is culturally acknowledged through clans, names, and lodges (Fox et al. 2017). Instead of ownership of a resource, we are encouraged to foster relationships with the land as family (Lariviere and Crawford 2013). Humans can learn a great deal about good relations from nonhumans who naturally understand the interconnectivity of life and that each individual life is dependent on the life of all others (Kimmerer 2015). Giving thanks is an important means of acknowledging relationships to the beings that sustain Anishinaabe bimaadiziwin (ways of living).

A gift creates a set of relationships that enables gratitude to be an inherent part of everyday life (Kimmerer 2015). There is no need for a word to literally express "thank you" in Anishinaabemowin because it is implied in Anishinaabe culture (Vukelich 2018). Culturally embedded gratitude comprises a deep awareness of all the land has given us and that everything we need to live already exists in nature (Kimmerer 2015). Gratitude cultivates an ethic of abundance that subverts scarcity-based economics. Although gratitude can be expressed in many different ways, it is usually done by making bagijigan (an offering). Among traditional Anishinaabe people, it is the honoured one who gives gifts and wealth is measured by having enough to give away (Kimmerer 2015). Anishinaabe society contains longstanding anti-capitalist practices, such as giveaways, that assist with the redistribution of wealth within communities (Simpson 2017).

The ethic of reciprocity involves a mutual exchange in which gift giving helps build positive relationships among humans and between humans and nonhumans (Giniwgiizhig 2013). In Anishinaabe culture, gifts come with a reciprocal obligation (Giniwgiizhig 2013; Kimmerer 2015). We can reciprocate with Anishinaabe bimaadiziwin and gkendaasowin. The Honourable Harvest entails giving something of value in return for what we are given and to sustain the ones who sustain us. This resolves the moral dilemma of needing to take life in order to live; Anishinaabe harvesting protocols ensure benefits are returned to the harvested in the chain of 
reciprocity (Kimmerer 2015). For Mshkodewashk's gifts, we can reciprocate by taking care of them, planting seeds, adding nutrients, and removing adjacent invasive plants.

Anishinaabe teachings acknowledge that whatever we are given is meant to be given away again; gifts are expected to circulate (Kimmerer 2015). Every person, human and nonhuman, is bound to each other in a reciprocal relationship. It is the harvester's moral obligation to make worthy use of the gift they receive from the plant or animal. By taking care of the spirit of the plant or animal, they are restored to a living condition (Lariviere and Crawford 2013). Animals' spirits are honoured guests at feasts, reborn as shakers or drums, and celebrated in the adornments of ceremonial regalia. The harvester and harvested are engaged in an endless cycle of reciprocities (Lariviere and Crawford 2013). As an extension of Chi Inaakonigewin (natural law), the '4 Rs' not only comprise humans and nonhumans' inherent right to bimaadiziwin (ways of living) and dibenindizowin (self-determination), but also humans' responsibilities to only harvest what is needed, reduce waste, give thanks, share what is harvested, and build reciprocal relationships. In the section that follows I explore how harvesting protocols apply to energy governance at a national scale in relation to Anishinaabeg resistance to the Line 3 replacement project.

\section{Line 3 and the Rights of Manoomin}

The Line 3 replacement program is heralded as the largest project in Enbridge history. The pipeline extends from Hardisty, Alberta to Superior, Wisconsin and was first put into service in 1968 without consultation with Indigenous peoples. The program would replace the 1,660 km of Line 3 to increase the existing capacity and carry tar sands' bitumen through Anishinaabe Aki to large refineries located in and around Minneapolis, Minnesota (Enbridge 2018). Enbridge applied to the National Energy Board (NEB) of Canada for the Canadian portion of the Line 3 replacement in November 2014. Along the route of Line 3 in the United States, only Minnesota requires a permit be obtained for new oil pipeline construction through the Public Utilities Commission (PUC). Enbridge applied to the Minnesota PUC for the American portion of the project in April 2015. That summer a series of Anishinaabe-led direct actions against Line 3 took place across Minnesota.

In November 2016, the Canadian federal government approved the pipeline replacement and construction commenced on the Canadian side of the border. The Assembly of Manitoba Chiefs appealed the NEB's decision in December 2016, challenging the approval of the project due to improper consultation. In response to premature construction in Canada and Wisconsin, resistance camps formed across northern Minnesota in February 2017 (including the Makwa Camp and White Earth Spirit Camp). Despite Anishinaabe intervenors' participation in the PUC hearings, cultural resources were excluded from the environmental impact statement first released by the Minnesota Department of Commerce in August 2017. The Minnesota Chippewa Tribal Government did not feel consulted through the colonial impact assessment process and conducted their own public hearings on Line 3 (LaDuke 2015). As a result of the Anishinaabeg hearings, the Tribal Government also released its own cumulative impact assessment in August 2017 that acknowledges interspecies equity, intergenerational equity, and the valuation of the intangible are an integral component of decision-making that is consistent with natural law (Minnesota Chippewa Tribe 2017). 
During this time, resistance to Line 3 continued to intensify, leading to arrests and hundreds of people rallying at the State Capitol. In January 2018 a joint tribal petition was submitted to the PUC on behalf of five Anishinaabeg communities. The petition requested consideration of historical grievances, as well as the cultural, cumulative, upstream, and downstream impacts. In June 2018 the PUC approved the pipeline route and, following the announcement, resistance camps formed outside the PUC office in St. Paul, Minnesota and at the Canada/US border (Spirit of the Buffalo Camp). In August 2018, the Fond du Lac, Mille Lacs, Red Lake, and White Earth Anishinaabeg filed a law suit with the Minnesota Court of Appeal, challenging the adequacy of the environmental impact statement. The Fond du Lac band reached an agreement with Enbridge in September 2018.

An important development in the struggle against Line 3 took place December 2018. The White Earth Anishinaabeg unanimously enacted the Rights of Manoomin ("the good seed" or wild rice), which recognizes that wild rice within the White Earth territory has the inherent right to exist, flourish, regenerate, and evolve, as well as the right to restoration, recovery, and preservation (White Earth Band of Minnesota Chippewa Tribe 2018). The Rights of Manoomin include but are not limited to: (1) the right to freshwater habitat, (2) the right to a healthy climate, and (3) the right to be free from patenting and genetic engineering. The scope of Manoomin's rights are far-reaching, Manoomin not only has legal rights but these rights are recognized by White Earth as being brought into action in the name of Manoomin as the real party in interest. Manoomin has the right to legally intervene in any action concerning their rights, and other parties to that action (lawyers for example) are unable to entirely represent Manoomin's particular interests. Manoomin has a very real and distinct role in decision-making. Moreover, Section 3 (Enforcement) outlines how the Tribal Government will take all necessary actions to protect and implement the Rights of Manoomin, and law enforcement are prohibited from arresting or detaining persons defending these rights. Any business or government that violates the Rights of Manoomin are punishable by tribal law and liable for any damages to Manoomin and their habitat. The Rights of Manoomin demonstrate that Anishinaabe people are involved in local actions on a national scale (Borrows 2018). This not only highlights the plurality of selfdetermining persons in Anishinaabe pipeline resistance, but also that national-level governance is embodied and embedded in local, place-based activities such as harvesting.

In June 2019 the Line 3 replacement project was further delayed when the Minnesota Court of Appeals declared that the previous version of the environmental impact statement was inadequate because it failed to specifically address the potential impacts of a spill into the Lake Superior watershed. Amidst ongoing blockades and protests, the Minnesota Commerce Department deemed that there is no significant threat to Lake Superior. At the time of writing, in December 2019, the Canadian portion of Line 3 replacement began operating, while a public forum was hosted in Duluth, Minnesota to gather comments on the state's revised environmental review. At the meeting, surrounded by armed police, Zhaabowekwe (Tara Houska), Anishinaabe tribal attorney, former National Campaigns Director of Honor the Earth, and founder of the Giniw collective (an anti-line 3 grassroots group), pointedly addressed the crowd: "You want to say it's for us? It's not for us. This has never been about us.... We've talked for years about this.... This is a sham process, it's built for somebody else, it's built for Enbridge to fuck over our watersheds... it's for the continued expansion of the tar sands. It has nothing to do with our people." (Houska 2019). Anishinaabe pipeline opponents continue to re-assert and centre responsibilities to the land and water, making explicit connections between Line 3, tar sands extraction, and the colonial capitalist system. 


\section{Kiimide, Nibi, Noodin, ge Giizis}

Drawing on the "4 Rs" (rights, responsibility, relationality, and reciprocity), this section will begin by contrasting Anishinaabe harvesting protocols with colonial framings of energy resources. I will then provide an overview of Anishinaabe understandings of four energy sources: Kiimide, Nibi, Noodin, ge Giizis (oil, water, wind, and solar). Although I do not know their whole stories and could not tell them here even if I did, I will summarize who they are and what we can learn from them regarding energy governance. In colonial framings, energy resources are typically categorized as either renewable or non-renewable. Renewable energy is understood as a naturally occurring, repetitive flow of energy in a local environment that is persistent and replenished as quickly as it is used, like solar, wind, and hydro power (Boyle 2004; Twidell and Weir 2015). In contrast, non-renewable energy is obtained from static, underground sources that have a finite supply on human timescales, like uranium and fossil fuels (Twidell and Weir 2015). There is partially a parallel between the renewable and non-renewable energy categories and the ethic of responsibility: harvesting only what is needed, taking only that which is given, reducing waste, and sharing benefits amongst the community.

In general, non-renewable energy is produced centrally and is expensive to distribute, while renewable energy is usually decentralized and expensive to concentrate and store (Twidell and Weir 2015). This means that while oil production has resulted in the uneven distribution of profits and impacts (Le Billon 2012), renewable energy could help attain more dispersed and evenly distributed energy systems (Twidell and Weir 2015). Current levels of fossil fuel consumption are not sustainable and constitute overharvesting according to Anishinaabe protocols. Fossil fuels are not being formed at a rate that is significant enough for replenishment (Twidell and Weir 2015). Fossil fuel extraction causes long-lasting damage, produces toxic waste, and violates virtually every precept of Anishinaabe harvesting ethics (Kimmerer 2015). The land needs to be violently cleared and broken into to remove fossil fuels at an industrial scale. Yet, Cariou's (2018) petrography (a method of developing photography using bitumen) expresses an alternative reciprocal relationship with bitumen sands that naturally occur near where he is from along the Athabasca river. When harvesting and processing bitumen, Cariou embodies traditional harvesting protocols in the creation of images that depict the immensity of tar sands' devastation and encourage self-reflection. There is strong potential for so-called renewable energy to be honourably harvested if the rights and responsibilities of nonhumans are not infringed upon and benefits are shared in an equitable manner. However, Indigenous ways of knowing emphasize relational, process-centred approaches to decolonization (Coulthard 2014; Simpson 2017). Despite renewability's parallel with the needs, waste, gift, and sharing components of the ethic of responsibility, the ' 4 Rs' and Anishinaabe framings of Kiimide (oil), Nibi (water), Noodin (wind), and Giizis (solar) power provide for a much more nuanced understanding of energy sources.

Mishipizhu (the great lynx) is key to understanding Anishinaabe framings of Kiimide (oil from the earth). This creature is the hybrid of a horned serpent and cat (Nelson 2013). Mishipizhu travels through water ways, underground caves, tunnels, and shale formations. In Anishinaabe culture, they are a mediator and protector of the underground that defends the balance of eco-social relations. They are often offered gifts and provide a moral lens for the relations between water and oil (Morriseau 1965; Nelson 2013). There are two main ways of 
looking at Mishipizhu: 1) as a victim of climate change, who like many other species is endangered, and/or 2) as a creator of climate change (Nelson 2013). Some Anishinaabe people argue that Mishipizhu is one of the causes of climate shifts because humans have forgotten to respect and pay tribute to them. They have been agitated by extractivism and are now orchestrating climate change to renew and balance the relationship between people, water, land, and sky.

Nibi (water) is the primary sacred element of life and a basic need for survival (McGregor 2013). Ni is derived from niya meaning "I am" and bi from bimaadiziwin, "a way of life" (Borrows 2018). They are sentient, a cherished relative, elder, and teacher with the power to cleanse and give life (Nelson 2013; Fox et al. 2017). In Anishinaabe culture it is women's responsibility to take care of the water (McGregor 2008). Each body of water is unique and has distinct characteristics. For the purposes of discussing hydroelectricity in this paper, I will focus on rivers. In Anishinaabemowin, zaagi (the mouth of a river) refers to love and observes the diversity and abundance of life at zaagi (Borrows 2018). The personality of rivers identifies standards about how we should act toward others and natural law provides us with analogies of a living being teaching us about love. Rivers are very old ancestors of the Anishinaabe and like other elderly people, rivers have rights and require community care (Fox et al. 2017). The rivers we know today are the same waters our ancestors interacted with, and the same ones that will be experienced by future generations (McGregor 2013). In this way, Nibi transcends spacetime, and connects generations in both healing and destructive ways, depending on humans' relationships with them. Much like Indigenous peoples, Nibi has experienced trauma to the extent that some waters are no longer able to fulfil their responsibilities to give and sustain life (McGregor 2013; Kimmerer 2015). Nibi continues to endure colonial violence, as demonstrated by the infamous Anishinaabe community of Grassy Narrows (McGregor 2013).

Much like water entities, individual winds also have unique personalities and preferences. The winds have many responsibilities to other living beings; they create caves for mosses to grow in and bears to hibernate in (Kimmerer 2003), as well as channels for birds' preferred migration routes (Manwell et al. 2009). Winds also typically pollinate plants, carry pheromones, and disperse moss spores. Kimmerer (2003) compares the jet stream through the stratosphere to a muddy river because it picks up sediment, seeds, spores, and insects on one shore and deposits them on another. In the interconnected web of reciprocity, Noodin has responsibilities to each of these beings, and similarly, Giizis has responsibilities to the winds. Different wind systems result from variations in pressure created by differences in solar heating (Boyle 2004).

Mishomis Giizis (Grandfather Sun) is an honoured teacher and relative, notably a role model for men. Giizis drives the solar powered process of photosynthesis and, like Nibi, has responsibilities to all living things, plants and animals. Their impacts are far reaching; variations in land surface and atmospheric temperature can affect climate, local hydrology, and precipitation regimes (Hernandez et al. 2014). When Mishomis Giizis shines, their light falls on everyone without discrimination and their path across the sky is reliable (Borrows 2018). Giizis encourages more equitable distributions of energy, while natural law is also attentive to the use of fossil fuels and the exploitation of minerals involved in the production of solar panels (Gerbinet et al. 2014). This paper demonstrates how rethinking energy governance can centre the perspectives of Mishipizhu, Nibi, Giizis, ge Noodin in decision-making. Ultimately, they remind us to acknowledge the power of the more-than-white/human world and natural law. 


\section{Gegoo ngiimkaan (something I found)}

Anishinaabe protocols can be applied to gwaabaw (harvesting energy) to renew reciprocal relationships and embody rights and responsibilities to the land. The ' 4 Rs' anchor an Anishinaabe critique of colonial extractivism, as well as a vision of what post-colonial society and energy decision-making processes could look like. Gwaabaw challenges colonial extractivism because Anishinaabe ways of knowing decentre humans as authority and invite us to ask: what can Mishipizhu, Nibi, Noodin, ge Giizis tell us about themselves in energy decision making? Gegoo ngiimkaan is that Anishinaabe harvesting protocols for gwaabaw make ecological, critical, and collaborative contributions to the way we think about energy.

Gwaabaw offers insights into ecological processes that could contribute to sustainability, based on learning from nonhuman persons. Direct communication with nonhuman persons is an accepted Anishinaabe methodology for attaining gkendaasowin (knowledge) (Johnston 1976; Dumont 2015; Pine 2016). The embodiment of land-based ways of knowing pushes back against colonial power imbalances in knowledge production by centring Anishinaabe gkendaasowin. This is important because the ontologies that frame the human-environment relationship and guide knowledge-making processes largely determine how ecosystems are treated (Pine 2016). From an ecological perspective, Anishinaabe gkendaasowin continues to be undermined by dominant institutions.

The long-standing power imbalance in knowledge production is rooted in universalist assumptions about the nature of reality (Sundberg 2014). All dominant paradigms (positivism, post-positivism, constructivism, and critical theory) treat knowledge as individual, and political ecology, grounded in critical theory, is no different (Wilson 2008). While multiculturalists claim that we exist in a world with many different cultural understandings of a single nature, Indigenous knowledge systems entail multinaturalist ontologies that recognize a multiplicity of truths (Wilson 2008; Coombes et al. 2012). Applying Anishinaabe harvesting protocols to energy development helps push back against the epistemic violence and colonial power relations underlying extractivism. An approach to energy based on Anishinaabe protocols is akin to a democracy of species: that is, decision making based on the reciprocal recognition of all beings could provide an important restraint on extractivism (Kimmerer 2015).

Gwaabaw protocols provide an opportunity to not only learn from nonhumans, but to actively collaborate with them in energy decision-making processes. Anishinaabe teachings provide an understanding that nonhumans not only talk to one another but have their own councils and decision-making structures (Kimmerer 2015). Indigenous peoples are already rebuilding organizations for energy governance that are equipped with self-determination and rooted in Indigenous ways of knowing and living. This is apparent in the resurgence of Indigenous governance taking place at Nimkii Aazhibikong (the Village of Thunder Mountain) (Commanda 2017), the Amisk (Beaver) Solar Project of the Beaver Lake Cree Nation that is pushing back against tar sands extraction (Simeon 2017), and the Nigig (Otter) Power Wind Farm of the Henvey Inlet Anishinaabek that is helping to foster economic self-determination (Ashawasegai 2014).

This paper has explored a particular convergence of ideas, and calls for further research into the structural transformations, workforce transitions, rights of nature, and epistemic diversification that would be needed to put gwaabaw into practice. Developing this work further should also involve exploring conditions and procedural arrangements that support dodemiwan (clan governance) and the embodiment of Indigenous governance in other collaborative contexts 
with the land. Moving forward, a key concept is ontological pluralism, the co-construction of knowledge based on engagement with multiple knowledge systems. Bridging multiple distinct epistemologies is integral to both the embodiment of the 4 Rs and challenging colonial extractivism.

\section{Conclusion}

Dewe'iganag (drums) are guests of honour at community feasts, we share our dish with Zhingwak ge Waawaashkeshi (pine and deer), Giizhik ge Mashkode Bizhiki (cedar and buffalo). In a sense, dewe'iganag are niizh manidoo (two-spirit) and have unique roles based on their gifts. Gender is what we do living an embodied experience. Gwaabaw supports the resurgence of niizh manidoog as political orders, in our lodges and understanding of the world. Gwaabaw necessitates changing not only how we understand, harvest, and distribute energy, but also how we organize decision-making structures. Actively involving nonhumans in decision-making and the co-production of knowledge involves broadening what is predominantly understood as a legitimate form of knowledge. Rebalancing human relationships with the land and accounting for nonhuman participation in energy decision making could have wide-ranging implications in practice: it could result in more holistic and culturally relevant impact assessments that help preserve Indigenous ways of knowing and living, and it could also help defy and stop colonial extractivism. Anishinaabe knowledge provides powerful ways of living that situate how humans can relate to energy sources in a sentient landscape and expands human notions of justice to include the rights, responsibilities, and reciprocal relationships of nonhuman beings.

\section{References}

Anthias, P. 2018. Indigenous peoples and the new extraction: From territorial rights to hydrocarbon citizenship in the Bolivian Chaco. Latin American Perspectives 45(5): 136153. doi: 10.1177/0094582X16678804.

Arens, C. J., J. C. Arens, N. S. Hogan, R. J. Kavanagh, F. Berrue, G. J. Van Der Kraak, and M. R. Van Den Heuvel. 2017. Population impacts in White Sucker (Catostomus Commersonii) exposed to oil sands-derived contaminants in the Athabasca River. Environmental Toxicology and Chemistry 36(8): 2058-2067. doi: 10.1002/etc.3735.

Ashawasegai, J. 2014. Nigig Power Corporation signs agreement to own and operate Henvey Inlet Wind project. Anishinaabek News, November 21. http://anishinabeknews.ca/2014/11/21/nigig-power-corporation-signs-agreement-to-ownand-operate-henvey-inlet-wind-project/.

Atari, D. O., I. Luginaah, X. Xu, and K. Fung. 2008. Spatial variability of ambient nitrogen dioxide and sulfur dioxide in Sarnia, "Chemical Valley," Ontario, Canada. Journal of Toxicology and Environmental Health 71(24): 1572-1581. doi: $10.1080 / 15287390802414158$.

Barnosky, A. D., N. Matzke, S. Tomiya, G. O. U. Wogan, B. Swartz, T. B. Quental, C. Marshall, et al. 2011. Has the Earth's sixth mass extinction already arrived? Nature 471(7336): 51-57. doi: 10.1038/nature09678.

Big-Canoe, K., and C. A. M. Richmond. 2014. Anishinabe youth perceptions about community health: Toward environmental repossession. Health and Place 26: 127-135. doi: 
10.1016/j.healthplace.2013.12.013.

Blair-Frasier, R. 2018. No fatalities, 15 injured in WI refinery blast. Industrial Maintenance \& Plant Operation, April 27. https://www.manufacturing.net/safety/news/13196342/nofatalities-15-injured-in-wi-refinery-blast

Borrows, J. 1997. Living between water and rocks: First Nations, environmental planning and democracy. University of Toronto Law Journal 47(4): 417-468. doi: 10.2307/825948.

- J. 2010. Canada's Indigenous Constitution. Toronto, ON: University of Toronto Press.

- 2016. Freedom and Indigenous constitutionalism. Toronto, ON: University of Toronto Press.

—. 2018. Earth-bound: Indigenous resurgence and environmental reconciliation. In Resurgence and reconciliation: Indigenous-settler relations and earth teachings, ed. M. Asch, J. Borrows, and J. Tully. Toronto, ON: University of Toronto Press, 49-82.

-. 2019. Law's Indigenous ethics. Toronto, ON: University of Toronto Press.

Boyle, G. 2004. Renewable energy: Power for a sustainable future. 2nd ed. New York, NY: Oxford University Press and the Open University.

Brewer, J. 2006. Indigenous origins of inalienable rights: natural law theory in Navajo culture. Loyola Journal of Public Interest Law 8(1): 37-44.

Bridge, G. 2011. Resource geographies 1: Making carbon economies, old and new. Progress in Human Geography 35(6): 820-834. doi: 10.1177/0309132510385524.

Burow, P. B., S. Brock, and M. R. Dove. 2018. Unsettling the land Indigeneity, ontology, and hybridity in settler colonialism. Environment and Society: Advances in Research 9(1): 5774. doi: 10.3167/ares.2018.090105.

Byun, K., and A. F. Hamlet. 2018. Projected changes in future climate over the Midwest and Great Lakes region using downscaled CMIP5 ensembles. International Journal of Climatology 38(1): 531-553. doi: 10.1002/joc.5388.

Cariou, W. 2018. "What is petrography?” Toxic tour of Canada's Chemical Valley, Aamjiwnaang First Nation, October 13. http://www.warrencariou.com/petrography

Carroll, C. 2014. Native enclosures: Tribal national parks and the progressive politics of environmental stewardship in Indian country. Geoforum 53: 31-40. doi:

10.1016/j.geoforum.2014.02.003.

Commanda, E. 2017. Introducing Nimkii Aazhabikong: Culture camp forver. MUSKRAT Magazine, June 21.

http://muskratmagazine.com/introducing-nimkii-aazhabikong-culture-camp-forever/.

Coombes, B., J. T. Johnson, and Howitt, R. 2012. Indigenous geographies I: Mere resource conflicts? The complexities in Indigenous land and environmental claims. Progress in Human Geography 36(6): 810-821. doi: 10.1177/0309132511431410.

Corbiere, M. A. 2013. How do /ni/, /taa/, /se/ and /shin/ alter meanings of Nishinaabekidwinan? In Anishinaabewin Niiwin, ed A. O. Corbiere, M. A. N. Corbiere, D. McGregor, and C. Migwans. M'Chigeeng: Ojibwe Cultural Foundation, 131-140.

Coulthard, G. 2010. Place against Empire: Understanding Indigenous anti-colonialism. Affinities: A Journal of Radical Theory, Culture, and Action. https://ojs.library.queensu.ca/index.php/affinities/article/view/6141.

—. 2014. Red skin, white masks: Rejecting the colonial politics of recognition. Minneapolis, MN: University of Minnesota Press.

Cragoe, N. G. 2017. Following the green path: Honor the Earth and presentations of Anishinaabe Indigeneity. Wicazo Sa Review 32(2): 46-70. 
Cryderman, D., L. Letourneau, F. Miller, and N. Basu. 2016. An ecological and human biomonitoring investigation of mercury contamination at the Aamjiwnaang First Nation. EcoHealth 13(4): 784-795. doi: 10.1007/s10393-016-1162-4.

Daigle, M. 2016. Awawanenitakik: The spatial politics of recognition and relational geographies of Indigenous self-determination. The Canadian Geographer 60(2): 259-269. doi: $10.1111 /$ cag. 12260.

Deloria, V. J. 2001. Power and place equal personality. In Power and place: Indian education in America, ed V. J. Deloria amd D. Wildcat. Golden, CO: Fulcrum Publishing, 21-28.

Doerfler, J., N. J. Sinclair, and K. H. Stark. 2013. Centering Anishinaabeg Studies: Understanding the world through stories. East Lansing, MI: Michigan State University Press.

Dumont, J. O. 2015. What was never told. Chippewas of the Thames First Nation, January 21April 30.

Durkalec, A., C. Furgal, M. W. Skinner, and T. Sheldon. 2015. Climate change influences on environment as a determinant of Indigenous Health: Relationships to place, sea ice, and health as an Inuit community. Social Science \& Medicine 17(26): 136-137. doi:

10.1016/j.socscimed.2015.04.026.

Enbridge. 2018. Line 3 replacement program. https://www.enbridge.com/Line3ReplacementProgram.aspx.

—. 2019. Enbridge energy infrastructure assets. https://www.enbridge.com/ /media/Enb/Documents/Factsheets/FS_EnergyInfrastructureAs sets.pdf?la=en.

Ferreira da Cunha, P. 2013. Rethinking natural law. New York, NY: Springer.

Fox, C. A., N. J. Reo, D. A. Turner, J. Cook, F. Dituri, B. Fessell, and M. Wilson. 2017. "The river is us; the river is in our veins": Re-defining river restoration in three Indigenous communities. Sustainability Science 12(4): 521-533. doi: 10.1007/s11625-016-0421-1.

Geniusz, W. M. 2009. Our knowledge is not primitive: Decolonizing botanical Anishinaabe teachings. New York, NY: Syracuse University Press.

Giniwgiizhig, H. F. 2013. An analysis of traditional Ojibwe civil chief leadership. $\mathrm{PhD}$ Dissertation, Faculty of the Graduate School, University of Minnesota. https://conservancy.umn.edu/bitstream/handle/11299/153332/Flocken_umn_0130E_13630. pdf? sequence $=1 \&$ is Allowed $=y$.

Gerbinet, S., S. Belboom, and A. Léonard. 2014. Life cycle analysis (LCA) of photovoltaic panels: A review. Renewable and Sustainable Energy Reviews 38: 747-753. doi: 10.1016/j.rser.2014.07.043.

Gormley, D. 1984. Aboriginal rights as natural rights. The Canadian Journal of Native Studies 4(1): 29-49. http://www3.brandonu.ca/cjns/4.1/gormley.pdf.

Grant, S. 2014. The Kalamazoo River spill: Pipelines, politics, and economies of knowledge. Master's Dissertation, Department of Geography \& Program in Planning, University of Toronto.

Gustafson, B., and N. Guzmán Solano. 2016. Mining movements and political horizons in the Andes. In Mining in Latin America: Critical approaches to the new extraction, ed. K. Deonandan and M. L. Dougherty. New York, NY: Routledge, 143-161.

Hearne, J. 2017. We all stand side by side: An interview with Elizabeth LaPensée. Studies in American Indian Literatures 29(1): 27-37.

Hernandez, R. R., S. B. Easter, M. L. Murphy-Mariscal, F. T. Maestre, M. Tavassoli, E. B. 
Allen, and M. F. Allen. 2014. Environmental impacts of utility-scale solar energy.

Renewable and Sustainable Energy Reviews 29: 766-779. doi: 10.1016/j.rser.2013.08.041.

Horn-Miller, K. 2013. What does Indigenous participatory democracy look like? Kahnawa:ke's community decision making process. Review of Constitutional Studies 18(1): 111-133.

Houska, T. 2019. This happened today too. This "process" is a sham.... Instagram post. https://www.instagram.com/p/B6RtwC1F4CD/?igshid=13qo28xqmx8hs\&fbclid=IwAR12i wHjw1NITD5FKOTGahPIgjRy-J2PJFCJkVDoo6srjTVSRHUe_lLa3oo.

Hunsberger, C., and S. Awasis. 2019. Energy justice and Canada's National Energy Board: A critical analysis of the Line 9 pipeline decision. Sustainability 11(3): 783. doi:10.3390/su11030783.

Hunt, S., and C. Holmes. 2015. Everyday decolonization: Living a decolonizing queer politics. Journal of Lesbian Studies 19(2): 154-172. doi: 10.1080/10894160.2015.970975.

Jalbert, K. 2017. ExtrACTION: Impacts, engagements, and alternative futures. London, UK: Routledge.

Jewell, E. M. 2018. Gimaadaasamin, we are accounting for the people: Support for customary governance in Deshkan Ziibiing. PhD dissertation, Faculty of Social and Applied Sciences, Royal Roads University.

Johnston, B. 1976. Ojibway heritage. New York, NY: Columbia University Press.

Jordaan, S. M. 2012. Land and water impacts of oil sands production in Alberta. Environmental Science and Technology 46(7): 3611-3617. doi: 10.1021/es203682m.

Kimmerer, R. 2003. Gathering moss: A natural and cultural history of mosses. Corvallis, OR: Oregon State University Press.

-. 2015. Braiding sweetgrass: Indigenous wisdom, scientific knowledge, and the teachings of plants. Minneapolis, MN: Milkweed Editions.

Kovach, M. 2009. Indigenous methodologies: Characteristics, conversations and contexts. Toronto, ON: University of Toronto Press.

LaDuke, W. 2015. The Thunderbirds versus the Black Snake: On Anishinaabe Akiing, an epic battle against oil pipelines is underway. Earth Island Journal 30(3): 44-48.

Lariviere, C. M., and S. Crawford. 2013. Indigenous principles of wild harvest and management: An Ojibway community as a case. Human Ecology 41(6): 947-960. doi: 10.1007/s10745-013-9568-x.

Le Billon, P. 2012. Wars of plunder: Conflicts, profits and the politics of resources. New York, NY: Columbia University Press.

Luginaah, I., K. Smith, and A. Lockridge. 2010. Surrounded by Chemical Valley and "living in a bubble": The case of the Aamjiwnaang First Nation, Ontario. Journal of Environmental Planning and Management 53(3): 353-370. doi: 10.1080/09640561003613104.

Manwell, J. F., J. G. McGowan, and A. L. Rogers. 2009. Wind energy explained. Chichester, UK: John Wiley \& Sons, Ltd.

McGregor, D. 2008. Linking traditional ecological knowledge and Western science: Aboriginal perspectives from the 2000 State of the Lakes Ecosystem Conference. The Canadian Journal of Native Studies 28(1): 139-158.

McGregor, D. 2013. Indigenous women, water justice and zaagidowin (love). Canadian Woman Studies 30(2, 3): 71-79.

Middleton, B. R. 2015. Jahat Jatitotodom: Toward an Indigenous political ecology. In The International handbook of political ecology, ed. R. Bryant. Northampton, MA: Edward Elgar Publishing, 561-576. 
Minnesota Chippewa Tribe. 2017. Anishinaabe Cumulative Impact Assessment on the Proposed Enbridge Line 3 Expansion and Abandonment Plan. Callaway, MN: Honor the Earth. https://www.mnchippewatribe.org/impact_assessment.html.

Morriseau, N. 1965. Legends of my people, the great Ojibway. Edited by S. Dewdney. Toronto, ON: The Ryerson Press.

Napoleon, V. 2013. Thinking about Indigenous legal orders. In Dialogues on human rights and legal pluralism, ed. R. Provost and C. Sheppard. Electronic resource: doi: 10.1007/978-94007-4710-4.

Navarrete-Segueda, A., M. Martínez-Ramos, G. Ibarra-Manríquez, J. Cortés-Flores, L. VázquezSelem, and C. Siebe. 2017. Availability and species diversity of forest products in a neotropical rainforest landscape. Forest Ecology and Management 406: 242-250. doi: 10.1016/j.foreco.2017.08.037.

Nelson, M. K. 2013. The hydromythology of the Anishinaabeg. In Centering Anishinaabeg Studies: Understanding the world through stories, ed J. Doerfler, N. J. Sinclair, and H. K. Stark. East Lansing, MI: Michigan State University Press, 213-233.

Nichols, J. 1995. The Ojibwe People's Dictionary. https://ojibwe.lib.umn.edu.

Norrgard, C. 2009. From berries to orchards. American Indian Quarterly 33(1): 33-61.

Pickren, G. 2019. The frontiers of North America's fossil fuel boom: BP, tar sands, and the reindustrialization of the calumet region. Journal of Political Ecology 26(1): 38-56. doi: 10.2458/v26i1.23106.

Pine, D. 2016. Ziisabaakodakaan: The place where sugar is made. MA Thesis, Geography and Planning, University of Toronto.

Preston, J. 2017. Racial extractivism and white settler colonialism: An examination of the Canadian tar sands mega-projects. Cultural Studies 31(2,3): 353-375. doi: 10.1080/09502386.2017.1303432.

Reyes-García, V., M. Guèze, A. C. Luz, J. Paneque-Gálvez, M. J. Macía, M. Orta-Martínez, and X. Rubio-Campillo. 2013. Evidence of traditional knowledge loss among a contemporary Indigenous society. Evolution and Human Behavior 34(4): 249-257. doi: 10.1016/j.evolhumbehav.2013.03.002.

Richmond, C., and N. Ross. 2009. The determinants of First Nation and Inuit health: A critical population health approach. Health and Place 15(2): 403-411. doi: 10.1016/j.healthplace.2008.07.004.

Riofrancos, T. 2017. Extractivismo unearthed: A genealogy of a radical discourse. Cultural Studies 31(2): 277-306. doi: 10.1080/09502386.2017.1303429.

Simeon, A. 2017. Beaver Lake Cree bring the power of the sun to tar sands ground zero. Ravent Trust. https://raventrust.com/2017/11/27/beaver-lake-cree-bring-the-power-of-the-sun-totar-sands-ground-zero/.

Simpson, L. B. 2013. Dancing on our turtle's back: Stories of Nishnaabeg re-creation, resurgence and a new emergence. Winnipeg, MB: Arbeiter Ring Publishing.

—. 2017. As we have always done: Indigenous freedom through radical resistance. Minneapolis, MN: University of Minnesota Press.

Simpson, L. B., and N. Klein. 2013. Dancing the world into being: A conversation with Idle No More's Leanne Simpson. YES! Magazine. http://www.yesmagazine.org/peacejustice/dancing-the-world-into-being-a-conversation-with-idle-no-more-leanne-simpson.

Sinclair, N. J. 2013. Nindoodemag bagijiganan: A history of Anishinaabeg narrative. PhD Dissertation, Faculty of Graduate Studies, The University of British Columbia. 
Sundberg, J. 2014. Decolonizing posthumanist geographies. Cultural Geographies 21(1): 33-47. doi: $10.1177 / 1474474013486067$.

Svampa, M. 2015. Commodities consensus: Neoextractivism and enclosure of the commons in Latin America. The South Atlantic Quarterly 114(1): 65-82.

Szeman, I. 2017. On the politics of extraction. Cultural Studies 31(2): 440-447. doi: 10.1080/09502386.2017.1303436.

Twidell, J., and T. Weir. 2015. Renewable energy resources. 3rd ed. London, UK: Taylor \& Francis Group.

Urquhart, I. T. 2018. Costly fix: Power, politics, and nature in the tar sands. North York, ON: University of Toronto Press.

Valdivia, G. 2008. Governing relations between people and things: Citizenship, territory, and the political economy of petroleum in Ecuador. Political Geography 27(4): 456-477. doi: 10.1016/j.polgeo.2008.03.007.

- 2015. Oil frictions and the subterranean geopolitics of energy regionalisms. Environment and Planning 47: 1422-1439. doi: 10.1177/0308518X15595764.

Valentine, R. 2001. Nishnaabemwin reference grammar. Toronto, ON: University of Toronto Press.

Valladares, C., and R. Boelens. 2017. Extractivism and the rights of nature: Governmentality, 'convenient communities' and epistemic pacts in Ecuador. Environmental Politics 26(6): 1015-1034. doi: 10.1080/09644016.2017.1338384.

Veltmeyer, H. 2013. The political economy of natural resource extraction: A new model or extractive imperialism? Canadian Journal of Development Studies/Revue canadienne d'études du développement 34(1): 79-95.

Veltmeyer, H., and P. Bowles. 2014. Extractivist resistance: The case of the Enbridge oil pipeline project in Northern British Columbia. The Extractive Industries and Society 1(1): 59-68. doi: 10.1016/j.exis.2014.02.002.

Vukelich, J. 2018. Ojibwe word of the day: Miigwech, "Thank you". https://www.facebook.com/james.vukelich.7/videos/vb.1102011293/10212978715718241/? type $=3$.

Wells, J., S. Casey-Lefkowitz, G. Chavarria, and S. Dyer. 2008. Danger in the nursery: Impact on birds of tar sands oil development in Canada's boreal forest. New York, NY: The Boreal Songbird Initiative, Natural Resources Defense Council, and Pembina Institute.

Westman, C., and T. Joly. 2019. Oil sands extraction in Alberta, Canada: A review of impacts and processes concerning Indigenous peoples. Human Ecology 47(2): 233-243. doi: 10.1007/s10745-019-0059-6.

White Earth Band of Minnesota Chippewa Tribe. 2018. Rights of Manoomin. Resolution No. 001-19-009. White Earth Reservation Business Committee.

https://whiteearth.com/assets/files/admin/resolutions/Administration\%20001\%20FY19\%20 Resolutions.pdf.

Willow, A. 2013. Doing sovereignty in Native North America: Anishinaabe counter-mapping and the struggle for land-based self-determination. Human Ecology 41(6): 871-884. doi: 10.1007/s10745-013-9593-9.

—. 2016. Indigenous extrACTIVISM in boreal Canada: Colonial legacies, contemporary struggles and sovereign futures. Humanities 5(3): 55. doi: 10.3390/h5030055.

Wilson, S. 2008. Research is ceremony: Indigenous research methods. Halifax, NS: Fernwood Publishing 
Wong, R. 2013. Ethical waters: Reflections on the Healing Walk in the tar sands. Feminist Review 103: 133-139.

Yerxa, J. 2014. Gii-kaapizigemin manoomin Neyaashing: A resurgence of Anishinaabeg nationhood. Decolonization: Indigeneity, Education \& Society 3(3): 159-166. 